\title{
A kutatásalapú tanulás, tanítás és tanárképzés lehetőségei a fizika oktatásában
}

A természettudomány oktatásának alapvetô módszere a kísérletezés. Fontos, hogy a tanár vagy a tanuló, vagy közösen a tanár és a tanuló végezzenek minél több és érdekes kísérletet, mérést, és ezekból vonjanak le következtetéseket. A kísérletezés minden bizonnyal javítja a tantárgy tanulói megitélését is. A fizika és a kémia tanulásához sokan elengedhetetlennek gondolják a feladatmegoldást is, hangsúlyozva gondolkodásfejlesztó funkcióját. Ez igényesebb feladatok esetében ténylegesen igy is van, amikor nem egyszerüen a képletekbe való behelyettesités jelenti a feladat megoldását. Azonban

a kép ennél sokkal árnyaltabb. Az ismeretszerzés menete nem redukálható le ennyire. A gondolkodás fejlesztésének is vannak egyéb módszerei, melyek jobban kapcsolódnak a természet megismeréséhez.

Mégpedig az olyan módszerek, amelyeknél a diákok lehetóséget

kapnak arra, hogy a megismerési folyamat tényleges részesei lehessenek, és ne csak egyszerüen be kelljen fogadniuk a mások által felhalmozott ismereteket. Ennek egyik kiváló módszere a kutatásalapú tanulás, melynek elterjesztésére széleskörú nemzetközi programok is indultak.

A kutatásalapú tanulást mint ismeretszerzési lehetőséget sokan keverik azzal, amikor diákjaikkal bekapcsolódnak egy éppen zajló kutatási folyamatba. Ez utóbbi nagyon fontos és jó dolog, de a kettő nem azonos. A kutatásalapú tanulás során azt szeretnénk, hogy a diákok mintegy átéljék, miként ismerjük meg a világot. Fontos, hogy az ismeretszerzés minden lépésének részesei lehessenek. Ök maguk fogalmazzanak meg természettudományos módszerekkel vizsgálható kérdéseket, alkossanak tesztelhető hipotéziseket, tervezzenek mérési lehetőségeket saját hipotéziseik tesztelésére, végezzék el azokat, kapjanak számszerü adatokat, melyeket kiértékelnek, következtetéseket vonnak le stb. Ez a folyamat a gondolkodás legszisztematikusabb formáit igénylő tevékenységek egyike (Adey és Csapó, 2012; Nagy L.-né, Korom, Pásztor, Veres és B. Németh, 2015). A kísérletezés továbbá jelentősen fejleszti a kézügyességet és a kreativitást, mert a rendelkezésre álló eszközöket figyelembe véve a kísérleti módszert is ki kell találni.

Fontos tudni, hogy egy adott életkori szakaszban lévő gyerekektöl milyen mértékü múveleti, gondolkodási tevékenységeket lehet elvárni. Például mennyire kell segíteni a problémák, az azok megoldásához tartozó feladatok konkrét megfogalmazását egy vizsgálat tervezése, majd annak elvégzése esetében. 10-14 éves korban, a természetismeret tanulásának, illetve a kémia, biológia, fizika tantárgyak belépésének időszakában az 
egyik fontos feladat az, hogy az érzelmek szerepét, vagy annak egy részét a racionalitás vegye át. Kicsit hasonlóan, ahogyan az emberiség történelmében is volt. Elöször a természeti jelenségeket nálunk felsőbbrendü lényeknek tulajdonították, majd a megismerés során azok egy része magyarázhatóvá vált. Ma már a villámlást nem Zeusz haragjának gondoljuk. (Bár valójában az sem érzelmi megközelítés, az is racionális, csak másféle.)

A természettudományok, a fizika oktatásához készült tantervekben, helyi tantervekben és egyéb dokumentumokban olvasható az, hogy fontos a diákok természettudományos szemléletének kialakítása és/vagy fejlesztése. De mit is jelent az, hogy természettudományos szemlélet? A kérdésre nem lehet egyetlen mondatban definíciót adni. Például a következőket lehet elmondani:

- A természet megismerhető, vannak természeti törvények, a világ nem random, összevissza múködik.

- A világot önmagából és önmagával magyarázzuk.

- A természet megismerésének vannak módszerei, szabályai, algoritmusai. Egyre több jelenséget tudunk megmagyarázni úgy, hogy alapvetőbb jelenségekre vezetjük vissza azokat. Ennek elengedhetetlen feltétele, hogy különböző fogalmakat konstruáljunk meg, melyekkel jellemezni tudjuk az adott dolgot, jelenséget. Ezek minél nagyobb részéhez számértékeket is rendelünk az összehasonlíthatóság miatt.

- A természetben előforduló jelenségek törvényekkel leírhatók, amihez a matematika jelrendszerét alkalmazzuk, amikor csak lehet.

A természettudomány feladata elsősorban a világ működésének leírása, a „hogyan müködik?" kérdésre való válaszok keresése, de egyre alapvetőbb és átfogóbb törvények segítségével, azokból kiindulva, sokszor hosszú logikai láncok felhasználásával. Ez jelenti azt, hogy a „Miért?”, „Mi az oka?” kérdésekre is választ keres. De el kell mondjuk azt is, hogy az olyan alapvető kérdésekre, mint például „Miért négy alapvető kölcsönhatás létezik, és azok miért olyanok?”, „Miért éppen akkora az elektron töltése, tömege?”, vagy „Mi az élet értelme?”, nem tud választ adni.

Vannak megismerési, kutatási módszerek a természet megismeréséhez, melyeket fentebb írtunk le. Empíria és elmélet összhangja: a dolgok lehetséges müködéséről, a megfigyelt jelenségek létrejöttének okáról hipotéziseket alkotunk, és ezeket megfigyelésekkel és kísérletekkel képesek vagyunk alátámasztani, vagy éppen megcáfolni. A természet leírásához sok esetben szükséges, hogy egyszerüsítő feltételeket vezessünk be, analógiákat és modelleket állítsunk fel, elkülönítsük a lényegest és a lényegtelentől, minél több tényezőt vegyünk fokozatosan figyelembe, és statisztikai, valószínüségi módszert alkalmazzunk.

Mai technikai világunk alapja a természettudomány. És a technika egyben segítője a további természettudományi kutatásnak és az oktatásnak egyaránt. A számítógépek alkalmazása nagymértékben segíti a kutatást a számítások gyorsabb elvégzésével, a hatalmas adatbázisok kezelésével, a szimulációknak a modellalkotásban és annak tesztelésében nyújtott lehetőségeivel. Ezzel egyben kitágult a vizsgálható jelenségek köre is. Továbbá az internet megteremtette a gyors tudásmegosztás lehetőségét.

Jelen írásban bemutatjuk a fizika oktatásához általunk kifejlesztett, a kutatásalapú tanulás alapjául szolgáló foglalkozásokat, melyeket ki is próbáltunk személyes közremüködésünkkel vagy tanárjelölt hallgatók bevonásával. 


\section{Példák a kutatásalapú megközelítésre a fizika oktatásában}

Munkánk során több változatos témájú és többféle feldolgozási lehetőséget felkínáló tanulási egységet dolgoztunk ki. Vannak kifejezetten kísérletes témájúak, és olyanok, amelyek elsősorban adatok feldolgozását igénylik, de előfordulnak inkább elméleti témájúak is. Célkitüzésünk az volt, hogy a diákokat konkrét tevékenységeken keresztül minél inkább közel vigyük a kutatási folyamathoz. Azt szeretnénk elérni, hogy a természettudomány és azon belül a fizika tanulása ne csak száraz tankönyvi leckék memorizálásából és unalmas szövegü feladatok megoldásából álljon, hanem a diákok nyerjenek bepillantást az új ismeretek keletkezésének folyamatába is. Ahhoz, hogy az ilyen feldolgozáshoz példákat találjunk, tanulmányoztuk a fizika történetét, elővettünk eredeti cikkeket, melyek egy jelenség felfedezéséről adnak hírt. Továbbá tanulmányoztuk napjaink kutatásait is, hogy megtaláljuk azokat a témákat, amelyek bevihetők az osztályterembe.

\section{Tudományos szövegek feldolgozása}

A fentebb írtak alapján jutottunk arra a gondolatra, hogy érdemes a diákoknak érdekes tudományos kutatással kapcsolatos szövegeket, esetleg eredeti írásokat olvasniuk, és ezen a módon feldolgozni akár a kötelező tananyagot, vagy egyszerúen csak példákat mutatni a tanultak alkalmazására. A foglalkozások kidolgozása során nemcsak a szakmai tartalmat tartottuk szem elött, hanem a példák alapján minden esetben elvártuk a diákoktól a kutatási folyamat nyomon követését is. Ehhez kérdéseket fogalmaztunk meg a kutatásról, annak egyes lépéseiről. A következő témákat dolgoztuk fel a szövegelemzés módszerével:

Halevő madarak zsákmányszerzése: kiváló példa az optikában tanult fénytörési törvény alkalmazására, melynek eredményeiről e lap hasábjain számoltunk be (Nagy, Horváth és Radnóti, 2013).

A rádium felfedezése: Marie Curie eredeti cikkének feldolgozása, melyről a Nukleon című online lapban számoltunk be (Radnóti és Nagy, 2013).

Szalmonellamentes lágytojás készítése, melyhez Kürti Miklósnak (1996) a Fizikai Szemlében megjelent írásából vettük az eredeti idézetet. Érdekessége ennek a feldolgozásnak még az, hogy a szöveg feldolgozása után, a szöveg alapján el is kellett készíteni a lágytojást.

A szövegek elemzését a tudományos kutatás szempontjából a következő kérdések mentén kértük a tanulóktól:

1. Mi volt a kutatási kérdés?

2. Mi volt a kutatás feltételezése (munkahipotézise)?

3. Milyen egyszerüsítésekkel éltek a kutatók a vizsgálatok során?

4. Milyen méréssorozatokat végeztek a kutatók?

5. Mi volt a kísérleti és az ellenőrző (kontroll) mérés?

6. Hogyan elemezték a kapott adatokat?

7. Milyen hibaforrások lehettek a mérés során?

8. Milyen következtetésekre jutottak a kutatók?

9. Milyen további kutatási kérdéseket tudnátok megfogalmazni a témával kapcsolatban?

10. Ti milyen vizsgálati eljárást, kísérleti berendezést terveztetek volna?

11. Milyen egyéb mennyiségeket mértetek volna meg és hogyan? 
Mint látható, a kérdések egyik része a szövegből ténylegesen kiolvasható információkra kérdezett rá, míg a másik része teret engedett a diákok kreativitásának. A tanórai szövegfeldolgozás menete általában a következő volt:

- a szöveg önálló olvasása,

- rövid írásos válaszok a szöveget követő kérdésekre egyénileg vagy csoportmunkában,

- közös megbeszélés.

Mindhárom modult tanárjelölt hallgatók is kipróbálták tanítási gyakorlatuk során, és a diákoktól kapott írásbeli válaszokat kiértékelték, majd megvitatták a tudományos kutatásokról szóló szövegek elemzésének előnyeit:

- Fejleszti a tanulók szövegértési képességét, ezzel segíti a természettudomány tanulásának folyamatát.

- Megmutatja, hogy a tudáshoz vezető út nem egyszerü. A tanuló a tankönyvekben már a kikristályosodott tudással találkozik. A valódi kutatások leírásából azonban azt is látja, hogy az igazi kutatómunka folyamata is tele van buktatókkal, tévedésekkel, zsákutcának bizonyuló irányokkal. Így talán jobban elfogadja azt, hogy egy számítási feladat megoldása vagy egy kísérlet elvégzése nehézséggel jár a számára. Érdemes felhívni a tanulók figyelmét az igazi kutatómunka és az általuk elvégzett mérések közötti párhuzamokra.

- Fejleszti a kritikus gondolkodást, például egy, a tömegkommunikációban megjelenő áltudományos vagy csak meggondolatlanul korán közölt tudományos hír olvasásakor a hír tartalmának részletesebb átgondolására késztet.

\section{Kísérletes vizsgálódások}

A szövegfeldolgozást kívánó modulok mellett több, empirikus vizsgálatokat is magában foglaló foglalkozást dolgoztunk ki, melyek egy részéről korábban már beszámoltunk:

- Galvánelemek összeállítása gyümölcsök és zöldségek felhasználásával.

- A Lebegö narancs (Floating orange) SAILS unit (Finlayson, McLoughlin, Coyle, McCabe, Lovatt és van Kampen, 2015) kipróbálása és továbbfejlesztése: Úszik-e a narancs, illetve egyéb gyümölcsök és zöldségek a vízben és különböző vizes oldatokban?

- Kémiai reakció sebessége hőmérsékletfüggésének vizsgálata (Nagy és Radnóti, 2015).

- Alkohol-víz elegy felületi feszültségének vizsgálata az összetétel függvényében (Nagy és Radnóti, 2015).

- A tömeg és a magasság közötti korreláció vizsgálata (Radnóti, 2015).

Mindegyik modulra jellemző, hogy a leírt kísérletek nem voltak nehezek, és nem igényeltek igazán mély előzetes ismereteket. Ugyanakkor alkalmasak voltak új természettudományos ismeretek elsajátítására, illetve a meglévő tudás elmélyítésére vagy a tévképzetek kijavítására a kutatási képességek fejlesztése mellett. Az ismertetett tevékenységek különböző korú tanulócsoportokkal (alsó tagozattól az egyetemig) és különböző oktatási színtereken (tanóra, szakkör, verseny) is elvégezhetők. A feladat mélységénél, a mérés előkészítésénél, a tanári szerep alakításánál, az elvárt eredményeknél természetesen figyelembe kell venni a színteret, a tanulók életkorát és felkészültségét. A fejlesztendő és értékelendő készségek a következők voltak:

- mérés megtervezése,

- hipotézisalkotás, várható függvénykapcsolat megfogalmazása, 
- adatok felvétele és megfelelő formában való ábrázolása,

- következtetések megfogalmazása,

- csoportmunka.

Különös gondot fordítottunk a hipotézisek megfogalmazására, melyet nagyon fontosnak gondolunk a természettudományos nevelés során. A hipotézis és a tapasztalat összevetését az alábbiak szerint kértük a diákoktól:

- A tényleges adatok ismeretében először csak a pontokat vegyék fel és jelenítsék meg az Excel program segítségével.

- A pontokra illesszék rá az Excel segítségével azt a függvénykapcsolatot, ami a hipotézis volt. Vizsgálják meg, hogy mennyire jó az illesztés, van-e egyéb, a mérési adatokra (vagy az azokból számolt mennyiségekre) jobban illeszkedő függvény!

- Illesszenek a pontokra egyéb, a hipotézisüktől eltérő függvényeket!

- Vizsgálják meg, melyik illesztés a legjobb!

- Vessék össze a legjobbnak adódott illesztést a hipotézissel!

A legtöbb esetben a diákok lineáris függést várnak a változók között. Viszont a függések a legtöbb esetben nem lineárisak. Ezért tartjuk fontosnak ennek tudatosítását. Ehhez dolgoztuk ki a fenti módszert, hogy a diákok tudatosan vizsgálják meg a tényleges tapasztalatot (a mérési eredményeket jelző pontok ábrázolása a koordináta-rendszerben), és vessék össze azt az előzetes elképzeléseikkel.

\section{A kutatásalapú tanulási módszer „terjesztése”: tanárképzés, tanártovábbképzés}

A kutatásalapú tanítás módszerét kétféle módon is terjesztettük a hallgatók között. Az egyik módszer szerint a leendő tanárok, illetve gyakorló pedagógusok lehetőséget kaptak arra, hogy iskolai szaktantermi körülmények között ők is végigcsináljanak a diákok számára kifejlesztett tanulási egységeket. Erre két modul esetében volt lehetőség:

- különböző gyümölcsök és zöldségek úszási tulajdonságainak vizsgálata,

- galvánelemek készítése gyümölcsök, zöldségek és fémdarabok felhasználásával.

Mivel egyetemi hallgatók voltak a kipróbálók, ezért jelentősen kibővítettük az eredetileg ajánlott feladatokat. Több szakmai ismeretet vártunk el, és méréssorozat, kvantitatív vizsgálat elvégzését is kértük.

További érdekessége volt a feldolgozásnak, hogy két tanár vezette. Ezáltal a hallgatók és a tanulók csoportmunkája mellett a foglalkozást vezető tanárok együttmüködésének kérdése is felmerült. A munkamegosztás az volt, hogy az egyikünk az egyik, másikunk a másik mérési feladat hallgatói megvalósítását, és az azt követő beszámolókat figyelte a felsorolt szempontok alapján mindhárom csoport esetében.

A hallgatók ugyanolyan helyzetbe kerültek a foglalkozás során, mint amilyenbe a diákjaik fognak kerülni egy hasonló tanóra során. Ezért a kipróbálással az is célunk volt, hogy a hallgatók ne csak halljanak egy módszerről, hanem ők maguk is tapasztalatokat szerezzenek. Így jobban átérzik, hogy a leendő diákjaik milyen élményekkel és problémákkal találkoznak majd hasonló helyzetekben. A foglalkozás alatt többször is felhívtuk a hallgatók figyelmét arra, hogy gondolják át, a diákokkal hogyan végeznék el a feladatot. A hallgatók a feladat végrehajtása során szembesülhettek azzal, hogy milyen hibalehetőségek, pontatlanságok adódhatnak még egy egyszerü kísérlet elvégzése során is. Így tudatosabban és megértőbben figyelhetnek ezekre akkor, amikor a tanulók végzik el a méréseket. Ezek a feladatok azt is tudatosíthatják a hallgatókban, hogy a legegyszerübb 
kísérletet, mérést is ki kell próbálni a tanárnak, mielőtt azt beviszi az órára: a hibalehetőségeken kívül azt is fel kell mérnie, hogy a rendelkezésre álló eszközökkel, anyagokkal a gyakorlatban megvalósítható-e az elméletileg tökéletesnek látszó mérés.

A megvalósítás egy 180 perces foglalkozás keretében történt. A hallgatók semmilyen elözetes információt nem kaptak, csak annyit tudtak, hogy kísérletezni fognak. Négyfős csoportok alakítására kértük őket. Fontosnak tartjuk, hogy a méréseket csoportokban végezzék el a résztvevők (a hallgatók és a tanulók egyaránt), hiszen így dolgozva fontos szociális és kommunikációs képességek is fejlődnek. Végül a 13 főből három csoport alakult, két négy fös és egy ötfös csoport. A csoportok kialakításába nem szóltunk bele, szimpátia alapján történt. A feladatok elosztását is a csoportokra bíztuk. A feladat megismerése után felmerült a hallgatókban, hogy a csoportok kialakításánál jó lett volna figyelembe venni azt is, hogy ki milyen szakos. Ez felveti azt a kérdést is, hogy a tanulókkal történő munka során a tanár a tanulókra bízza-e a csoportok kialakítását, vagy ő végezze el azt. Mindkét megoldás létrehozhat konfliktusokat a gyerekek között: ha a tanulók végzik el a csoportbeosztást, egy-egy népszerütlen gyerek kimaradhat a válogatásból. Ha a tanár osztja be a csoportokat, olyan gyerekek kerülhetnek egy csoportba, akik között rossz a viszony. Természetesen ennek a problémának a megoldásában sokat segít, ha a tanár jól ismeri a tanítványait. Az is kérdés lehet, hogy a tanulók már ismert képességei alapján hogyan történjen a csoportbeosztás. Ha nagyon eltérő képességü tanulók kerülnek egy csoportba, fennáll a veszélye annak, hogy a feladatokat föként az ügyesebbek végzik el. Ez az értékelésnél is nehézséget jelent, hiszen a tanár inkább csak a csoportok munkájára tud figyelni, nem az egyénekére. Ha homogén csoportokat alakítunk ki, akkor pedig az fordulhat elö, hogy nagy lesz az eltérés a feladatok sikeressége között. Az ideális megoldás az, ha a tanulók különböző képességei a jó feladatmegosztást teszik lehetővé: például az egyiknek jó ötletei vannak, a másik jól tud szerelni, a harmadik pontosan tud mérni, a negyedik szépen rajzol. Ha már végeztek a tanulók hasonló kísérletet, akkor kiderültek ezek a képességek, így akár a tanár, akár a diákok ezek szerint végezhetik el a csoportbeosztást.

Az alábbi feladatlapot kapták meg a csoportok. A feladatlap, valamint a kikészített eszközök és anyagok orientálták a hallgatók kísérleti munkáját. Az eszközök és anyagok egy részét minden csoport egységesen megtalálhatta a saját tálcáján, a többit pedig szükség szerint a közös tálcáról vehették el. 


\section{Különböző gyümölcsök és zöldségek úszási tulajdonságainak vizsgálata Galvánelemek készítése gyümölcsök, zöldségek és fémdarabok felhasználásával}

Anyagok és eszközök az egyes csoportok számára:

- néhány gyümölcs/zöldség, például mandarin vagy narancs, alma, uborka (nyers és savanyú), burgonya 2 darab, citrom

- víz, cukor, só

- kanál, pohár, vonalzó, hőmérö, melegítőeszköz, pH-papír

- csiszolópapír vagy -vászon (finom szemcsés)

- pénzérmék, illetve egyéb elektródának alkalmas fémek, mint például szögek, csavarok,

- csoportonként 2 darab feszültségmérö, krokodilcsipesz (4 db), vezeték (4 db)

- zseblámpaizzó

- mobiltelefon, laptop Excel programmal (lehetőleg a hallgatóknál is legyen az ábrázoláshoz, csoportonként $2 \mathrm{db}$ ), projektor

A csoport vezessen jegyzőkönyvet a munka során, amely tartalmazza:

- a csoport által megfogalmazott kutatási kérdéseket,

- a feltett kérdések vizsgálatához megtervezett kísérletek leírását és az elözetes elképzeléseket, hipotéziseket,

- a függvénykapcsolatok jellegének hipotézisként való megfogalmazását,

- a kísérletek során felmerülő problémákat, azok megoldásait,

- a kísérletek során tett megfigyeléseket, eredményeket, mérési adatokat,

- a mérési adatok felhasználásával készült Excel grafikonokat és az azokhoz tartozó függvényillesztéseket, melyek jóságáról az $\mathbf{R}^{\mathbf{2}}$ ad felvilágosítást,

- az előzetes hipotézisekkel való összevetést,

- elhanyagolások, közelítések, hibalehetőségek meggondolását,

- a következtetéseket.

A foglalkozás menete a következő volt:

1. Kutatási kérdések összeírása, majd közös megbeszélés és döntés arról, hogy melyik csoport mit fog csinálni, milyen vizsgálatokat fog elvégezni (30 perc).

2. A csoportok gyakorlati munkája (90 perc).

3. A csoportok beszámolója a munkájukról (40 perc).

4. Értékelés, kiterjesztési lehetőségek (20 perc).

A három csoport mindegyike kicsit mást csinált, differenciált csoportmunkában. Azonban voltak közös elvárások:

1. A kiválasztott gyümölcsök és zöldségek úszási tulajdonságainak vizsgálata.

2. Úszás esetén az oldatból kilógó rész magasságának ábrázolása grafikonon a vízben feloldott cukor/só mennyiségének függvényében. (Az egység: 1 kanálnyi mennyiség.)

3. Különböző galvánelemek készítése a kiválasztott anyagok felhasználásával.

4. A burgonyából, valamint rézből és horganyzott acélból álló galvánelem által létrehozott kapocsfeszültség időbeli változásának mérése és ábrázolása grafikonon. 
Segítő kérdések, az előzetes tudás mozgósítása:

- Milyen esetben merül le egy test egy folyadékban?

- Mi az úszás és mi a lebegés feltétele?

- Hogyan lehet elérni, hogy egy eredetileg lemerülö test lebegjen, netán ússzon?

- Mitől függ az, hogy egy folyadékban úszó test kilógó része milyen magas?

- Hogyan lehet ezt megváltoztatni?

- Szükséges-e, hogy a folyadék közeg valódi oldat legyen?

- Hol használunk elemeket a mindennapi életben?

- Mi a különbség az elemek és az akkumulátorok között?

- Miből származik egy elem energiája?

- Melyek a galvánelem részei?

- Mitől függ egy galvánelem elektromotoros ereje? Ez hogyan vizsgálható?

- Egy adott galvánelem elektromotoros ereje időben állandó marad-e? Ez hogyan vizsgálható?

Felhívtuk a hallgatók figyelmét arra, hogy egy-egy új téma bevezetésénél az általános és a középiskolások esetében is nagyon fontos az előzetes ismeretek feltárása. Ezekre lehet építeni, ezeket kell beépíteni a rendszerezett tudásba, vagy korrigálni, a tévképzeteket javítani. Azt is feladatként kapták a hallgatók, hogy gyüjtsék össze, hogy egy-egy tanulói korosztálynál milyen elözetes ismeretekre számíthatnak.

A két vizsgálatsorozatot egyszerre végezték a csoportok. Itt fontos elem volt a feladatok ésszerű megosztása a csoporttagok között.

\section{A hallgatói munka értékelése}

A Vizsgálat tervezése készség esetében mindhárom csoport a „Haladó” kategóriába tartozik, mely egyetemi hallgatók és ilyen egyszerü feladatok esetében el is várható. Az adatok gyüjtése rendben megtörtént, melyeket logikus táblázatokba rendeztek a hallgatók.

A Hipotézisalkotás készségkategóriák közül viszont mindhárom csoport csak a „Középhaladó” szintet teljesítette. Mindegyik csoport megfogalmazta ugyan némileg matematikai formában hipotézisét, ami szerint lineáris, illetve a fizika szakos hallgatókból álló csoport esetében telítésbe menő görbe várható. Azonban ezt nem a tanult fizikai leírás alapján tették meg. Ez ténylegesen nem könnyű még a kutatói szinten sem. Továbbá szemmel láthatóan az ilyen jellegü megközelítés nem volt ismerős a hallgatók számára, annak ellenére, hogy számtalan laborgyakorlatot csináltak már végig. Azokon azonban minden esetben előre megadott „recept” alapján kellett dolgozniuk. A hazai oktatás nem fejleszti a valódi kutatói képességet még az egyetemen sem.

A Grafikus ábrázolásra mi, a kipróbálást vezető tanárok, azt vártuk, hogy sokkal jobban fog menni a hallgatóknak. Ebben csalatkoztunk. A kért függvényillesztés csak egy grafikon esetében történt meg. Tehát a hallgatókat a „Középhaladó” szintre soroltuk be.

A Következtetések bemutatása rendben volt. A hallgatók összevetették a kapott eredményeiket az általuk megfogalmazott hipotézisekkel. Ez már közelítette a „Haladó” szintet.

Érdekes volt, hogy az egyetemi hallgatók körében is megjelentek fiatalabb tanulókra jellemző téves elképzelések. Például a feltárni kívánt függvénykapcsolatot a legtöbben lineárisnak gondolták, holott egyik sem az. A folyadékba helyezett gyümölcs esetében csak az egyik fizika szakos hallgató gondolta végig, hogy a görbének telítésbe kell menni, és a lineáris közelítés csak a kis sürüségváltozások esetében lesz jó. A galvánelem kapocsfeszültségének változását is többen egyszerüen lineárisnak gondolták, bár itt elhangzott más is, például logaritmikus kapcsolat. 


\section{A tapasztalatok összegzése}

A fentiek alapján látható, hogy egészen más jellegú készülés szükséges, mint amikor a tanár frontális módon elóadást tart, vagy demonstrációként bemutat egy kisérletet. Ténylegesen ezekben az esetekben is meg kell terveznie a kérdéseket, meg kell csinálnia a demonstrációs kísérletet, de alapvetóen a tanár irányítja a folyamatot, pontosan látva, illetve inkább tervezve, hogy mi lesz a következó lépés. A fenti esetben is a tanár irányít, ô tudja, hogy ténylegesen hová szeretne eljutni. De annak módjában sokkal nagyobb szerepet szán a diákoknak, jobban bevonja óket a tanulási folyamatba, teret adva egyéni ötleteiknek, javaslataiknak. Ez utóbbiak esetében viszont nagyon nagy szüksége van a magas szintú szakmai tudására, hogy a diákok által javasolt út ténylegesen járható-e, vagy módositani kell azt. At kell gondolnia, hogy meddig lehet engedni a diákokat, hogy egyéni útjaikat kövessék, akkor is, ha már az elején látszik, hogy az rossz, de mégis fontos tapasztalat lesz.
Nagyon fontosnak tartjuk azt, hogy az adott, feldolgozandó kutatási témában a tanár szakmailag teljesen otthonosan mozogjon, hiszen az ilyen jellegü foglalkozásokon a diákoknak sokféle kérdése, ötlete lehet. Ezekre nem is lehet felkészülni, éppen ezért kell a háttértudás. De a tervezésnél, például a segítő kérdések elözetes átgondolásához is szükséges a magas szintü szakmai tudás.

Pedagógiai vonatkozásban fontos, hogy a tanárnak legyen gyakorlata a különbözö kollektív munkaformák alkalmazásában, lehetőleg már az adott diákcsoporttal is. Elöször nem kutatási feladat megoldását, hanem egyszerü csoportmunka alkalmazását javasoljuk, majd fokozatosan kapjanak a diákok egyre nagyobb önállóságot. A tanár fokozatosan vonuljon „háttérbe”. Ez utóbbi sem könnyü, hiszen hazánkban eléggé elterjedt vélekedés az, hogy a tanár áll a középpontban, ő a tudás forrása még akkor is, ha bizonyos részfeladatokat a diákkal végeztet el.

Azt is tudni kell, hogy nem minden téma alkalmas kutatásalapú feldolgozásra. Az is furcsa, szokatlan a hazai gyakorlat számára, hogy a tanárok a diákoktól hipotéziseket kérjenek. A tanulói hipotézisek értékelése is fontos szempont. Nem az a ,jó" hipotézis, ami majd a mérések során ténylegesen beigazolódik, hanem arra kell figyelemmel lenni, hogy az mennyire kidolgozott, ad-e konkrét tesztelhetö előrejelzést a tanuló előzetes tudása, vélekedései alapján.

Arra, hogy ténylegesen beválik-e a hipotézis, a következtetések levonásánál lehet kitérni és értékelni. Arra kell figyelemmel lenni, hogy a diákok összevessék hipotézisüket a tényleges tapasztalatokkal, és azokat értékeljék aszerint, hogy bevált-e az előrejelzésük, vagy nem. Ha igen, miért, ha nem, miért nem?

Idősebb diákok esetében célszerü minél több méréssorozatot végeztetni, a hipotézisek megfogalmazását is minél inkább mate-

matikai alakban megtenni. Milyen jellegü függvénykapcsolatra számítanak: egyenes, vagy fordított arányosság, esetleg egyéb kapcsolat? A diákok alkalmazzák előzetes tudásukat ebben a szakaszban, származzon az akár a köznapi tapasztalatból, akár az iskolában tanultakból. Az IKT-eszközök felhasználása, például az az informatikaórán megismert 
Excel program remek lehetőséget ad a tanárok kezébe arra, hogy bemutassák a természeti törvények függvénykapcsolat jellegét.

A hagyományos feladatmegoldások esetében a végeredmény sokszor egy számérték, általában mértékegységgel. A középfokú oktatásban ritkán térünk ki arra, hogy a kapott számértékek valójában egy függvény egy-egy adott pontjának koordinátái.

Az is látható, hogy egy hasonló jellegü feldolgozáshoz milyen jellegü tanári készülés szükséges. Ennek elengedhetetlen része az, hogy maga a tanár is végigcsinálja azt a méréssorozatot, melyet diákjaitól kíván! Csak ekkor lehet elképzelése arról, hogy diákjai milyen jellegü problémákkal kerülhetnek szembe a téma feldolgozása során. Saját tapasztalatai és természetesen a diákok várható előzetes tudása alapján kell terveznie a segítő kérdéseket, a szükséges anyagokat, eszközöket és az egyéb segédleteket. Mi szerepeljen a feladatlapon, mi az, amit már elvárhat a diákoktól? Fontos annak végiggondolása, hogy diákjainak milyen ötletei lehetnek.

A fentiek alapján látható, hogy egészen más jellegü készülés szükséges, mint amikor a tanár frontális módon előadást tart, vagy demonstrációként bemutat egy kísérletet. Ténylegesen ezekben az esetekben is meg kell terveznie a kérdéseket, meg kell csinálnia a demonstrációs kísérletet, de alapvetően a tanár irányítja a folyamatot, pontosan látva, illetve inkább tervezve, hogy mi lesz a következő lépés. A fenti esetben is a tanár irányít, ö tudja, hogy ténylegesen hová szeretne eljutni. De annak módjában sokkal nagyobb szerepet szán a diákoknak, jobban bevonja öket a tanulási folyamatba, teret adva egyéni ötleteiknek, javaslataiknak. Ez utóbbiak esetében viszont nagyon nagy szüksége van a magas szintű szakmai tudására, hogy a diákok által javasolt út ténylegesen járható-e, vagy módosítani kell azt. Át kell gondolnia, hogy meddig lehet engedni a diákokat, hogy egyéni útjaikat kövessék, akkor is, ha már az elején látszik, hogy az rossz, de mégis fontos tapasztalat lesz.

Jelen esetben mi tanácsoltuk a hallgatóknak, hogy készítsenek fényképsorozatokat. A feszültség-idő függvény felvételéhez a feszültségmérő mellé tegyenek egy órát, melyet időnként fényképezzenek le. Így nem kell arra külön figyelni, hogy például valaki 5 percenként olvassa le a feszültséget. A vízben úszó gyümölcs esetében is érdemes fényképeket készíteni a kilógó rész magasságának meghatározásához a különböző koncentrációk esetében. A leolvasásnál pedig arra kell figyelni, hogy a pohár méretét vegyék mindig azonosnak a fénykép nagyításánál/kicsinyítésénél, és úgy mérjék meg a folyadékból kilógó rész hosszát.

\section{Tanárjelölt hallgatók kutatási képességeinek fejlesztése}

A másik módszer, ahogy a hallgatók felé terjeszteni tudtuk a módszert, az általunk kifejlesztett foglalkozások tanulókkal, tényleges oktatási környezetben való kipróbálása. Ebbe a feldolgozásba olyan tanár szakos hallgatók kapcsolódtak be, akik az úgynevezett hosszú tanítási gyakorlatukat végezték. Az új alapokra helyezendő tanárképzés fontos eleme az úgynevezett kutatásalapú képzés, hogy a képzésből kikerülő tanárok képesek legyenek hasonló jellegü osztálytermi kutatások elvégzésére, melyre példát láthattak. A hallgatók további feladata volt még az, hogy az általuk elvégzett úgynevezett osztálytermi kutatásról tényleges kutatási jegyzökönyvet, esettanulmányt írjanak.

A hallgatók az összes általunk kifejlesztett foglalkozást kipróbálták. Különösen kedvelt téma volt azonban a tömeg-magasság modul, melyről korábbi írásban beszámoltunk, de az idén is több hallgató választotta. A tudományos szöveg feldolgozásával kapcsolatos modulokat is több osztályban próbálták ki a hallgatók. Ezekben az esetekben a válaszok kvantitatív elemzése is megtörtént hallgatói projekt keretében. A levelezős hallgatók 
esetében egy választott modul kipróbálása és arról beszámoló, elemzés készítése külön tantárgyként is megjelenik.

A hallgatók érdekesnek és tanulságosnak találták a feladatot. Többen leírták, hogy aktív tanár korukban ők is fognak hasonló feladatokat végeztetni diákjaikkal. Továbbá a statisztikai jellegü kiértékelést is hasznosnak találták, melynek elemeit többen a különböző osztályok dolgozateredményeinek elemzéséhez is felhasználták. A kutatásalapú tanulás beépítésének haszna a tanárképzésbe, hogy a hallgató megtanulja a módszert: kipróbálja és tudatosítja magában. Megtanul elemzést, beszámolót írni, amit később cikkírásnál, pályázatírásnál is hasznosíthat.

A foglalkozásokról, azok kipróbálásáról tanártovábbképzés keretében is beszámoltunk. Ezen olyan gyakorló tanárok vettek részt, akik a későbbiek során, vagy már jelenleg is mentortanárként müködnek, illetve szeretnének ilyen feladatot ellátni.

\section{Összegzés}

Tanulmányunkban a kutatásalapú tanítás/tanulás lehetőségeit mutattuk be a fizika oktatása során. Kitértünk a különböző kutatási készségek értékelési lehetőségeire is, különös tekintettel a tanulói hipotézisekre. Általánosságban is foglalkoztunk a hipotézisek szerepével az oktatásban. Beszámoltunk továbbá arról, hogy miként igyekeztünk a módszert terjeszteni a tanárjelöltek bevonásával, illetve a tanártovábbképzések során.

\section{Irodalomjegyzék}

Adey, Philip és Csapó Benő (2012): A természettudományos gondolkodás fejlesztése és értékelése. In: Csapó Benő és Szabó Gábor (szerk.): Tartalmi keretek a természettudomány diagnosztikus értékeléséhez. Nemzeti Tankönyvkiadó, Budapest. 17-58.

Finlayson, O., McLoughlin, E., Coyle, E., McCabe, D., Lovatt, J. és van Kampen, P. (2015, szerk.): SAILS inquiry and assessment units. Volume 2. 71-80. http://results.sails-project.eu/units

Kürti Miklós (1996): Mivel foglalkozik egy öreg fizikus? Fizikai Szemle, 46. 11. sz. 388.

Nagy Lászlóné, Korom Erzsébet, Pásztor Attila, Veres Gábor és B. Németh Mária (2015): A természettudományos gondolkodás online diagnosztikus értékelése. In: Csapó Benő, Korom Erzsébet és Molnár Gyöngyvér (szerk.): A természettudományi tudás online diagnosztikus értékelésének tartalmi keretei. Oktatáskutató és Fejlesztő Intézet, Budapest. 35-116.
Nagy Mária és Radnóti Katalin (2015): Híd a közoktatás és a felsőoktatás között. Iskolakultúra, 25. 1. sz. 51-77. DOI: 10.17543/iskkult.2015.1.51

Nagy Mária, Horváth Gábor és Radnóti Katalin (2013): Kutatási szöveg tanórai feldolgozása. Iskolakultúra, 23. 9. sz. 96-109.

Radnóti Katalin (2015): Milyen magasak és milyen nehezek vagyunk? Iskolakultúra, 25. 10. sz. 110-126.

Radnóti Katalin és Adorjánné Farkas Magdolna (2015): A kutatás alapú tanulás lehetőségei a fizikaórán. Fizikai Szemle, 65. 6. sz. 198-204.

Radnóti Katalin és Nagy Mária (2013): A rádium felfedezése. Kutatási szöveg feldolgozása a fizika- és/ vagy a kémiaórán. Nukleon, 6. 3. sz. 